\title{
Antimicrobial activity of Caesalpinia sappan L. extract against skin flora
}

\author{
Mi Kyung Hwang ${ }^{1}$ Yong Hyun Lee $^{2} \cdot$ Dong Chung Kim ${ }^{1}$ iD

\section{소목(Caesalpinia sappan L.) 추출물의 피부 상재균에 대한 항균 활성}

\author{
황미경 ${ }^{1} \cdot$ 이용현 ${ }^{2} \cdot$ 김동청 ${ }^{1}$
}

Received: 12 January 2021 / Accepted: 16 February 2021 / Published Online: 31 March 2021

(C) The Korean Society for Applied Biological Chemistry 2021

\begin{abstract}
Antimicrobial activity of an aqueous extract from Caesalpinia sappan L. was investigated against skin flora such as Escherichia coli, Staphylococcus aureus, Cutibacterium acnes, and Malassezia furfur. The yield and polyphenol content of the aqueous extract were $14.01 \pm 0.81 \%$ and $487.5 \pm 19.69 \mu \mathrm{g} / \mathrm{mg}$ extract, respectively. The minimum inhibitory concentration of the aqueous extract against $E$. coli, $S$. aureus, $C$. acnes, and $M$. furfur was $0.875,1.750,1.750$, and $1.750 \mathrm{mg} / \mathrm{mL}$, respectively. In disc diffusion test, the aqueous extract of $C$. sappan $\mathrm{L}$. increased the clear zone in a dose-dependent manner. The aqueous extract inhibited the microbial growth in a concentration-dependent manner.
\end{abstract}

Keywords Antimicrobial activity · Aqueous extract ' Caesalpinia sappan L. Minimum inhibitory concentration $\cdot$ Skin flora

\section{서 론}

소목(Caesalpinia sappan L.)은 예부터 천연 염료 및 한약재로 널리 사용되어 왔다. 소목의 나무 중심부인 심재에는 탄닌, 정

\section{Dong Chung Kim $(\bowtie)$}

E-mail: kimdc@chungwoon.ac.kr

${ }^{1}$ Department of Chemical Engineering, Chungwoon University, Incheon 22100, Republic of Korea

${ }^{2}$ Leadb Co., Ltd, Incheon 21697, Republic of Korea

This is an Open Access article distributed under the terms of the Creative Commons Attribution Non-Commercial License (http://creativecommons. org/licenses/by-nc/3.0/) which permits unrestricted non-commercial use, distribution, and reproduction in any medium, provided the original work is properly cited.
유 성분, 배당체, 페놀화합물, 지방산 등과 같은 화학 성분들[1] 과, brazilin, brazilide A, sappanone B, sappanchalcon, 3deoxysappanchalcone, butein 및 protosappanin 등의 생리활성 물질들이 함유되어 있다[2]. 소목 심재의 염료성 화합물의 주성 분은 무색의 flavonoid 구조를 갖는 brazilin인데 공기 중에 산 화되면 홍색의 brazilein이 되어 천연 염료로 사용되고 있다[3]. 소목 심재에 들어있는 식물성 폴리페놀은 항산화 및 항균 등의 생리학적 역할을 하는 중요한 물질로 보고되었다[4]. 소목의 심 재로부터 얻어지는 소목 추출물은 항염증 [5], 항암[6,7], 항산화 [8] 및 면역조절[9] 활성을 가지고 있고, 소목의 3-deoxysappanone, brazilin 및 protosappanin A 성분은 당뇨에 의해 야기되는 2 차 합병증 치료에 효과적인 것으로 알려졌다[10].

소목 추출물은 Escherichia coli, Staphylococcus aureus 및 Salmonella typhimurium에 대한 항균 활성을 보여주었고[11], 소 목의 brazilin은 S. aureus에 대해 우수한 항균성을 가지는 것으 로 나타나 소목 추출물을 천연 항균제로서 활용하려는 시도가 이루어지고 있다[12]. 소목 추출물로부터 분리된 brazilin은 여 드름 유발균인 Propionibacterium acnes에 대해서 $0.5 \mathrm{mg} / \mathrm{mL}$ 의 최소저해농도(minimum inhibitory concentration, MIC)를 갖 는다고 보고되었고[13], 충치 균인 Streptococcus mutans에 대해 서도 항균 작용을 나타내는 것으로 알려졌다[14].

세균성 질병의 치료를 위해 수많은 항균 물질이 개발되었으 나 내성균의 증가와 독성으로 인해 자연 친화적이고 안전한 천 연 항균제의 중요성이 크게 부각되고 있다[15]. 소목 추출물은 천연 항균 소재 중의 하나로 관심을 받아 왔고, 주로 식품 및 화장품 분야에서 소목 추출물의 항균력에 관한 연구가 이루어 지고 있다[16]. 그러나 소목의 항균 효과에 대한 다양한 연구에 도 불구하고 아직까지 여드름, 비듬 및 가려움증을 유발하는 피 부 미생물에 대한 항균 활성 연구는 부족한 실정이다.

따라서 본 연구에서는 피부 상재 미생물인 E. coli, S. aureus, Cutibacterium acnes 및 Malassezia furfur를 대상으로 소목 열 수추출물의 항균 활성을 체계적으로 확인하고자 하였다. 기존의 
연구에서 소목 메탄올 추출물의 E. coli 및 S. aureus에 대해 항균 활성을 보고한 바 있지만 MIC 및 생육저해환 확인에 그 치고 있다[11-13]. 본 연구에서는 소목의 식품 및 화장품 산업 에서의 활용도를 높이기 위해 소목을 열수로 추출하여 $\mathrm{MIC}$ 확 인뿐만 아니라 농도에 따른 생육저해환 측정, 액체배양에서 농 도와 시간에 따른 피부 상재균의 증식에 미치는 영향을 확인함 으로써 소목 추출물의 항균 활성을 체계적으로 정리하였고, 특 히 여드름 유발균인 C. acnes와 비듬 유발 진균인 M. furfur에 대한 항균 효과를 확인함으로써 소목 추출물을 피부질환 완화 를 목적으로 하는 화장품 소재 및 식품 산업에서의 천연 항균 소재로서의 활용 가능성을 검토하고자 하였다.

\section{재료 및 방법}

\section{실험재료}

소목은 인도네시아산으로 대구광역시 약령시장에서 건조 분말 을 구입하여 200 mesh sieve로 거른 후 시료로 사용하였다. Folin 시약, sodium carbonate, gallic acid는 Sigma Aldrich (St. Louis, MO, USA) 제품을 사용하였다. 그람음성균인 Escherichia coli는 돼지고기에서 분리 후 동정하여 사용하였고, 그람양성균인 Staphylococcus aureus ATCC 29213, Cutibacterium acnes ATCC 6919와 진균인 Malassezia furfur ATCC 14521 은 American Type Culture Collection (Manassas, VA, USA) 에서 분양받았다. 미생물 배양 배지들은 $\mathrm{BD}$ bioscience (Franklin Lakes, NJ, USA)의 제품을 사용하였는데, E. coli 배 양은 Luria-Bertani broth/agar를, S. aureus와 C. acnes 배양은 tryptic soy broth/agar를, M. furfur 배양은 yeast mold broth/ agar를 사용하였다.

\section{소목 열수 추출 및 폴리페놀 함량}

소목 분말을 10 배 $(\mathrm{w} / \mathrm{v})$ 의 증류수에 침지시켜 고압멸균기(ES-315, Tomy Digital Biology, Tokyo, Japan)로 $100{ }^{\circ} \mathrm{C}$ 에서 60 분 추출 하였고 원심분리 $(3,000 \times \mathrm{g}, 10$ 분 $)$ 하여 소목 추출물을 얻은 후 여 과지로 거르고 회전감압농축기(Eyela, Tokyo Rikakikai, Tokyo, Japan)로 농축하여 실험에 사용하였다.

소목 열수추출물의 폴리페놀 함량은 Folin-Denis 방법으로 확 인하였다[17]. 소목 추출물에 Folin 시약을 넣어 상온에서 5분 간 반응시키고 $6 \%$ sodium carbonate 용액을 첨가하여 상온에 서 1시간 방치한 후 $725 \mathrm{~nm}$ 에서 흡광도를 측정하여 $\mu \mathrm{g}$ gallic acid equivalents (GAE)/mg extract로 나타내었다.

\section{항균 활성 평가}

소목 열수추출물의 피부상재균에 대한 $\mathrm{MIC}$ 를 확인하였다[14]. 소목 추출물을 멸균된 배지로 $1 / 2$ 씩 단계적으로 희석하고 96 well plate에 $100 \mu \mathrm{L}$ 씩 넣은 후 각각의 균주를 $10^{5} \mathrm{cfu} / \mathrm{mL}$ 농 도가 되게 희석한 것을 $100 \mu \mathrm{L}$ 첨가하여 24 시간 동안 $37^{\circ} \mathrm{C}$ 에 서 배양한 후 흡광광도계(Multickan FC, Thermo Fisher Scientific, Waltham, MA, USA)로 $595 \mathrm{~nm}$ 의 흡광도를 측정하여 균주가 성장하지 않은 소목 추출물의 농도를 $\mathrm{MIC}$ 로 하였다.

디스크 확산법으로 소목 열수추출물의 항균 활성을 확인하였 다[16]. 멸균된 $8 \mathrm{~mm}$ paper disc에 소목 추출물을 농도별로 80 $\mu \mathrm{L}$ 씩 접종하여 준비하였다. $37^{\circ} \mathrm{C}$ 에서 24 시간 동안 배양된 각 각의 균주를 $10^{5} \mathrm{cfu} / \mathrm{mL}$ 로 희석하여 agar plate에 고루 퍼지도 록 도말한 후 준비한 paper disc를 배지 표면에 가볍게 놓고 24 시간 동안 $37^{\circ} \mathrm{C}$ 에서 배양한 후 생육저해환(clear zone)의 크 기를 측정하였다. 음성대조군으로 증류수를, 양성대조군으로는 4\% 1,2-hexanediol을 사용하였다.

소목 열수추출물의 균 증식 억제 효과는 흡광도법을 통해 확 인하였다[18]. $37^{\circ} \mathrm{C}$ 에서 24 시간 동안 배양된 각각의 균주를 $10^{4}$ $\mathrm{cfu} / \mathrm{mL}$ 농도가 되도록 희석한 후 소목 추출물을 농도별로 첨가 하여 혼합하였다. 혼합액 $200 \mu \mathrm{L}$ 을 96 well plate에 분주하여 24 시간 동안 $37{ }^{\circ} \mathrm{C}$ 에서 배양하였으며 2시간 간격으로 $595 \mathrm{~nm}$ 의 흡광도를 측정하여 균 증식 정도를 확인하였다.

\section{결과 및 고찰}

소목의 항균 활성에 관한 기존의 연구는 주로 메탄올 추출물을 대상으로 이루어 졌다[11-13]. 식품과 화장품 산업에서 천연물 의 추출에 가장 효율적이고 안전한 용매는 물이기 때문에 본 연구에서는 소목 추출의 공정 단순화와 활용도를 높이기 위해 소목을 열수로 추출하여 항균 효과를 확인하였다. 소목 열수추 출물의 수율은 $14.0 \pm 0.8 \%$ 였고, 총 폴리페놀 함량은 추출물 $\mathrm{mg}$ 당 $487.5 \pm 19.7 \mu \mathrm{g} \mathrm{GAE}$ 로 나타났다(Table 1). 소목은 추출 용매 에 따라 수율이 달라지는데, 메탄올 추출은 $12.3 \%$, 에탄올 추 출은 $10.2 \%$, ethyl acetate 추출은 $5.0 \%$ 로 열수 추출에 비해 수율이 낮게 나타났다[19]. 이는 용매의 극성이 감소할수록 식 물 조직에 다량 들어있는 당류, 아미노산 및 무기질 등의 극성 성분들이 잘 추출되지 않아 수율이 낮아지는 것으로 볼 수 있 다[20].

소목 열수추출물의 폴리페놀 함량을 생리활성이 높다고 알려 진 다른 약용 식물과 비교하였을 때, 두충잎 추출물 $(64.1 \mu \mathrm{g} / \mathrm{mg})$ [20], 사자발약쑥 추출물 $(106.9 \mu \mathrm{g} / \mathrm{mg})$ [21], 모시풀 추출물 $(105.0$ $\mu \mathrm{g} / \mathrm{mg}$ ) [22]에 비하여 매우 높은 것으로 나타났다. 폴리페놀 화 합물은 항산화, 항염, 항박테리아, 당화 억제 및 면역 조절 등 의 생리활성을 나타내는 것으로 보고되었다[23,24]. 폴리페놀 화 합물의 우수한 항균 활성은 기존 항생제에 저항성이 있는 박테 리아 문제를 해결하는데 좋은 대안으로 여겨져 왔다[25]. 특히 폴리페놀 화합물 중 flavonoid는 우수한 항균 효과를 가지고 있 고, 그 작용 기작으로는 박테리아의 직접 사멸, 항생제의 상승 적 활성화 및 박테리아의 병원성 억제 등이 알려져 있다[26].

피부 세균과 진균에 대한 소목 열수추출물의 MIC는 Table 2 에 나타내었다. 소목 열수추출물의 E. coli에 대한 MIC는 0.875 $\mathrm{mg} / \mathrm{mL}$ 이었고, S. aureus, C. acnes 및 M. furfur에 대한 MIC 는 $1.75 \mathrm{mg} / \mathrm{mL}$ 이었다. 소목 열수추출물은 피부 세균뿐만 아니 라 진균에 대해서도 우수한 항균 효과를 보여주었다. Lee와 $\operatorname{Min}$ [27]은 소목 메탄올 추출물의 E. coli와 S. aureus에 대한

Table 1 Yield and polyphenol content of Caesalpinia sappan L. extract

\begin{tabular}{cc}
\hline \hline Yield (\%) & polyphenol content ${ }^{2}(\mu \mathrm{g} \mathrm{GAE} / \mathrm{mg}$-extract $)$ \\
\hline $14.0 \pm 0.8^{1)}$ & $487.5 \pm 19.7^{1)}$ \\
\hline
\end{tabular}

${ }^{19}$ Data represented means and SD of triplicate measurements

${ }^{2)}$ Polyphenol content was expressed as gallic acid equivalents (GAE) 
Table 2 Minimum inhibitory concentration of Caesalpinia sappan L. extract

\begin{tabular}{ccccc}
\hline \hline \multirow{2}{*}{ Sample } & \multicolumn{4}{c}{ Minimum inhibitory concentration $(\mathrm{mg} / \mathrm{mL})$} \\
\cline { 2 - 5 } & E. coli & S. aureus & C. acnes & M. furfur \\
\hline C. sappan extract & 0.875 & 1.750 & 1.750 & 1.750 \\
\hline
\end{tabular}

Table 3 Antimicrobial activities of Caesalpinia sappan L. extract against skin flora

\begin{tabular}{|c|c|c|c|c|c|}
\hline \multirow{2}{*}{\multicolumn{2}{|c|}{ Treatment agents }} & \multicolumn{4}{|c|}{ Clear zone size $^{1)}(\mathrm{mm})$} \\
\hline & & E. coli & S. aureus & C. acnes & M. furfur \\
\hline \multicolumn{2}{|c|}{ Control } & $0.00 \pm 0.00$ & $0.00 \pm 0.00$ & $0.00 \pm 0.00$ & $0.00 \pm 0.00$ \\
\hline \multicolumn{2}{|c|}{ 4\% 1,2-Hexanediol } & $13.00 \pm 0.57$ & $12.00 \pm 0.47$ & $11.00 \pm 0.57$ & $10.67 \pm 0.57$ \\
\hline \multirow{5}{*}{ C. sappan extract } & $0.438 \mathrm{mg} / \mathrm{mL}$ & $8.00 \pm 0.00$ & $9.00 \pm 0.00$ & $8.00 \pm 0.00$ & $8.00 \pm 0.00$ \\
\hline & $0.875 \mathrm{mg} / \mathrm{mL}$ & $9.34 \pm 0.57$ & $9.00 \pm 0.00$ & $8.00 \pm 0.00$ & $10.66 \pm 0.57$ \\
\hline & $1.750 \mathrm{mg} / \mathrm{mL}$ & $12.00 \pm 1.00$ & $12.00 \pm 1.00$ & $9.34 \pm 0.57$ & $11.33 \pm 0.57$ \\
\hline & $3.500 \mathrm{mg} / \mathrm{mL}$ & $15.34 \pm 0.57$ & $15.34 \pm 0.57$ & $13.33 \pm 0.57$ & $15.66 \pm 0.57$ \\
\hline & $7.000 \mathrm{mg} / \mathrm{mL}$ & $18.00 \pm 0.82$ & $17.66 \pm 0.47$ & $17.66 \pm 0.47$ & $19.33 \pm 0.57$ \\
\hline
\end{tabular}

${ }^{1)}$ Data represented means and SD of triplicate measurements
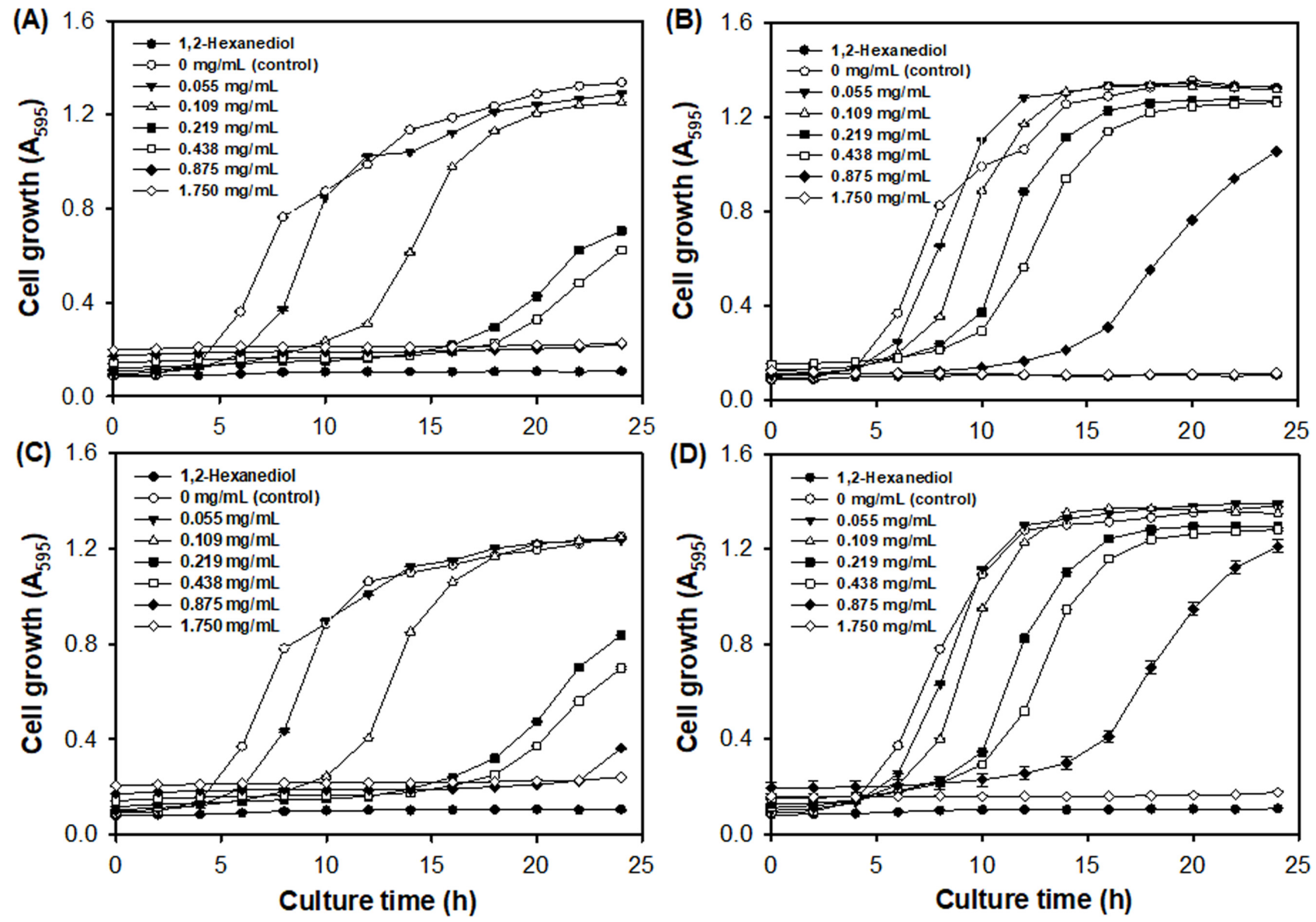

Fig. 1 Effect of concentrations of Caesalpinia sappan L. extract on growth inhibition against Escherichia coli (A), Staphylococcus aureus (B), Cutibacterium acnes (C), and Malassezia furfur (D). 4\% 1,2-hexanediol was used as a positive control. Data were means and SD of triplicate measurements 
$\mathrm{MIC}$ 를 각각 3.125 및 $1.563 \mathrm{mg} / \mathrm{mL}$ 로 보고하였고[27], Choi 등 [28]은 소목 메탄올 추출물의 S. aureus에 대한 $\mathrm{MIC}$ 를 1.6 $\mathrm{mg} / \mathrm{mL}$ 로 보고하여 본 연구와 큰 차이가 없었다. 따라서 소목 을 메탄올이 아닌 물로 추출하여도 항균 활성에는 큰 차이가 없기 때문에 소목의 산업적 활용도를 높이기 위해 열수 추출이 바람직한 것으로 사료된다.

소목 열수추출물의 E. coli, S. aureus, C. acnes, M. furfur 에 대한 항균 효과를 디스크 확산법으로 확인한 결과는 Table 3 에 나타내었다. 소목 열수추출물은 $3.5 \mathrm{mg} / \mathrm{mL}$ 의 농도에서 $E$. coli, S. aureus, C. acnes 및 M. furfur에 대해서 각각 15.34, 15.34, 13.33 및 $15.66 \mathrm{~mm}$ 의 생육저해환을 보여주었다. 양성대 조군으로 사용된 1,2-hexanediol은 $4 \%(\mathrm{w} / \mathrm{w})$ 의 농도에서 $E$. coli, S. aureus, C. acnes 및 M. furfur에 대해서 각각 13.00 , $12.00,11.00$ 및 $10.67 \mathrm{~mm}$ 의 생육저해환을 보여주었다. 소목 열 수추출물은 그람음성균, 그람양성균 및 진균에 대해 모두 농도 의존적으로 균의 생육을 저해하였고, $3.5 \mathrm{mg} / \mathrm{mL}$ 이상의 농도에 서는 양성대조군보다 우수한 항균 활성을 보여주었다. Madhubala 등[29]은 소목 메탄올 추출물이 $5.0 \mathrm{mg} / \mathrm{mL}$ 의 농도 에서 S. aureus에 대해 $15.0 \mathrm{~mm}$ 의 생육저해환을 나타낸다고 보 고하였고[29], Lee와 Min [27]은 소목 메탄올 추출물이 50.0 $\mathrm{mg} / \mathrm{mL}$ 의 농도에서 E. coli와 $S$. aureus에 대해 각각 13.0 및 $26.0 \mathrm{~mm}$ 의 생육저해환을 나타낸다고 보고한 바 있다. 본 연구 의 소목 열수추출물은 $E$. coli와 $S$. aureus 뿐만 아니라 여드름 유발 세균인 C. acnes와 비듬 유발 진균인 M. furfur에 대해서 도 낮은 농도에서 우수한 항균 활성을 나타냄을 알 수 있었다. 소목 열수추출물의 배양 시간에 따른 농도별 항균 효과를 확 인한 결과를 Fig. 1에 나타내었다. 그람음성균인 E. coli, 그람 양성균인 $S$. aureus와 C. acnes, 진균인 M. furfur은 모두 추출 물을 첨가하지 않은 음성대조군에서 배양 4시간 이후 급격한 균의 증식이 나타났고, 양성대조군인 $4 \%(\mathrm{w} / \mathrm{w})$ 1,2-hexanediol 첨가 시에는 24 시간 동안 균의 증식이 전혀 일어나지 않았다. E. coli의 경우, 소목 열수추출물을 $0.875 \mathrm{mg} / \mathrm{mL}$ 의 농도 이상으 로 첨가 시에는 전혀 증식하지 않았고, 그보다 낮은 농도에서 는 농도의존적으로 증식이 억제되었다(Fig. 1A). S. aureus, C. acnes 및 M. furfur의 경우, 소목 열수추출물을 $1.750 \mathrm{mg} / \mathrm{mL}$ 의 농도 이상으로 첨가 시에는 전혀 증식이 일어나지 않았고, 그 보다 낮은 농도에서는 농도의존적으로 균의 증식이 억제되었다 (Fig. 1B D). 소목 열수추출물은 액체 배양에서도 E. coli와 $S$. aureus 뿐만 아니라 C. acnes와 M. furfur에 대해서도 우수한 증식억제 활성을 갖는 것으로 확인되었다. 기존의 연구에서 소 목 메탄올 추출물과 에탄올 추출물은 $100 \mathrm{ppm}$ 이상의 농도에 서 S. aureus의 증식을 완전히 억제하였고[18], 소목의 $75 \%$ 에 탄올 추출물은 $100 \mathrm{ppm}$ 의 농도에서 $S$. aureus의 증식을 완전히 억제한다고 알려졌다[30].

소목 추출물은 동남아시아 등지에서 음료와 식품 첨가물로 사용되고 있고, 또한 치약과 스킨 케어 등의 화장품 원료로도 활용되고 있다[31]. 우리나라에서 소목 추출물은 식품 원료로 허가되지 않았고 인체 피부를 대상으로 하는 화장품 원료로는 사용이 가능한데, 과량의 소목 추출물을 경구 투여한 동물 실 험에서도 독성이 없는 것[32]으로 나타나 향후 천연 색소 및 보 존 효과를 가진 식품 첨가제로 활용할 수 있을 것이다.

이상의 결과에서 소목의 열수추출물은 피부상재균인 E. coli,
S. aureus, C. acnes, M. furfur에 대해서 우수한 항균 활성을 보여주었다. 따라서 소목 열수추출물은 항균 식품 소재뿐만 아 니라 피부질환의 예방과 완화를 목적으로 하는 스킨케어 제품 에 활용가능성이 높을 것으로 사료된다.

\section{초 록}

소목(Caesalpinia sappan L.) 열수추출물의 피부상재균 (Escherichia coli, Staphylococcus aureus, Cutibacterium acnes, Malassezia furfur)에 대한 항균 활성을 확인하였다. 소목 열수 추출물의 수율과 폴리페놀 함량은 각각 $14.01 \pm 0.81 \%$ 과 $487.5 \pm 19.69 \mu \mathrm{g} / \mathrm{mg}$-추출물로 나타났다. 소목 열수추출물의 $E$. coli, S. aureus, C. acnes 및 M. furfur의 증식에 대한 최소저 해농도는 각각 $0.875,1.750,1.750$ 및 $1.750 \mathrm{mg} / \mathrm{mL}$ 이었다. 디 스크 확산법에서 소목 열수추출물의 처리량에 비례하여 생육저 해환이 증가하였다. 소목 열수추출물은 농도에 비례하여 피부상 재균의 생육을 억제하였다.

Keywords 소목(Caesalpinia sappan L.) · 열수 추출 · 최소 저해농도 · 피부상재균 · 항균 활성

감사의 글 본 논문은 제 1 저자의 청 운대학교 석사학위 논문을 바탕으로 작 성되었습니다.

\section{References}

1. Namikoshi M, Saitoh T (1987) Homoisoflavonoids and related compounds. IV. Absolute configurations of homoisoflavonoids from Caesalpinia sappan L. Chem Pharm Bull 35: 3597-3602

2. Nirmal NP, Rajput MS, Prasad RGSV, Ahmad M (2015) Brazilin from Caesalpinia sappan heartwood and its pharmacological activities: A review. Asian Pac J Trop Med 8: 421-430

3. Park SZ, Kang JY, Seol DW, Yang HM, Lee JM, Choi HJ, Han SY, Jeon DW (2010) Effect of the change of $\mathrm{pH}$ condition on the dyeing using Caesalpinia sappan. J Fash Bus 14: 138-150

4. Maltese F, Erkelens C, van der Kooy F, Choi YH, Verpoorte R (2009) Identification of natural epimeric flavanone glycosides by NMR spectroscopy. Food Chem 116: 575-579

5. Hikino H, Taguchi T, Fujimura H, Hiramatsu Y (1977) Antiinflammatory principles of Caesalpinia sappan wood and of Haematoxylon campechianum wood. Planta Med 31: 214-220

6. Ueda JY, Tezuka Y, Banskota AH, Tran QL, Tran QK, Harimaya Y, Saiki I, Kadota S (2002) Antiproliferative activity of Vietnamese medicinal plants. Biol Pharm Bull 25: 753-760

7. Park KJ, Yang S, Eun YA, Kim SY, Lee HH, Kang H (2002) Cytotoxic effects of Korean medicinal herbs determined with hepatocellular carcinoma cell lines. Pharm Biol 40: 189-195

8. Nguyen MT, Awale S, Tezuka Y, Ueda JY, Tran QL, Kadota S (2006) Xanthine oxidase inhibitors from the flowers of Chrysanthemum sinense. Planta Med 72: 46-51

9. Choi SY, Yang KM, Jeon SD, Kim JH, Khil LY, Chang TS, Moon CK (1997) Brazilin modulates immune function mainly by augmenting $\mathrm{T}$ cell activity in halothane administered mice. Planta Med 63: 405-408

10. Li WL, Zheng HC, Bukuru J, Kimpe ND (2004) Natural medicines used in the traditional Chinese medical system for therapy of diabetes mellitus. J Ethnopharmacol 92: 1-21

11. Wongkrajang Y, Manamuti C, Saraya S, Temsiririrkkul R, Peungvicha P, 
Cheewansirisuk C (2007) Antioxidant and preservative properties of Caesalpinia sappan L. extract. Planta Med 73: P127

12. Nirmal NP, Panichayupakaranant $P$ (2015) Antioxidant, antibacterial, and anti-inflammatory activities of standardized brazilin-rich Caesalpinia sappan extract. Pharm Biol 53: 1339-1343

13. Batubara L, Mitsunaga T, Ohashi H (2010) Brazilin from Caesalpinia sappan wood as an antiacne agent. J Wood Sci 56: 77-81

14. Kwon HJ, Kim YH, Han KI, Jeon M, Han MD (2012) Antimicrobial activities and adherence inhibition on Streptococcus mutans by ethyl acetate extract from Caesalpinia sappan L. J Dent Hyg Sci 12: 155-162

15. Otvos Jr L (2000) Antibacterial peptides isolated from insects. J Pept Sci 6: 497-511

16. Ahn DJ, Kwak YS, Kim MJ, Lee JC, Shin CS, Jeong KT (2000) Screening of herbal plant extracts showing antimicrobial activity against some food spoilage and pathogenic microorganisms. Korean J Med Crop Sci 8: 109-116

17. Folin O, Denis W (1912) On phosphotungstic-phosphomolybdic compounds as color reagents. J Biol Chem 12: 239-243

18. Lee SK (2003) Antimicrobial activities of Caesalpinia sappan against animal husbandry disease. Korean J Microbiol Biotechnol 31: 242-249

19. Lim DK, Choi U, Shin DH (1996) Antioxidative activity of some solvent extract from Caesalpinia sappan L. Korean J Food Sci Technol 28: $77-82$

20. Kim DC (2020) Antioxidative activities of ethanolic extracts of Duzhong (Eucommia ulmoides Oliver) leaf and bark. J Appl Biol Chem 63: 259265

21. In MJ, Kim KH, Kim DC (2020) Antioxidant and anticoagulant activities of Ganghwa medicinal mugwort (Artemisia princeps Pampanini) extract. J Appl Biol Chem 63: 439-442
22. Kim C, In MJ, Kim DC (2015) In vitro antioxidant activity of ethanol extract from Boehmeria nivea L. leaves. Food Eng Prog 19: 76-81

23. Fraga CG, Galleano M, Verstraeten SV, Oteiza PI (2010) Basic biochemical mechanisms behind the health benefits of polyphenols. Mol Aspects Med 31: 435-445

24. Xie Y, Chen X (2013) Structures required of polyphenols for inhibiting advanced glycation end products formation. Curr Drug Metab 14: 414431

25. Xie Y, Yang W, Chen X, Xiao J (2014) Inhibition of flavonoids on acetylcholine esterase: binding and structure-activity relationship. Food Funct 5: 2582-2589

26. Tangney CC, Rasmussen HE (2013) Polyphenols inflammation, and cardiovascular disease. Curr Atheroscler Rep 15: 324

27. Lee JY, Min KJ (2011) Antimicrobial activity and bactericidal activity of Caesalpinia sappan L. extract. J Environ Health Sci 37: 133-140

28. Choi I, Chang HS, Yun YM, Um JC (2002) Antimicrobial activity of medicinal herbs against Staphylococcus aureus and Salmonella gallinarum. Kor J Microbiol Biotechnol 30: 177-183

29. Madhubala S, Poongothai M, Mahesh Kumar E (2018) Antibacterial and anti acne activity of Caesalpinia sappan L. and Cinnamomum verum J. Presl-A comparison. Int J Adv Res Biol Sci 5: 118-122

30. Shin DH, Kim MS, Han JS (1997) Antimicrobial effect of ethanol extracts from some medicinal herbs and their fractionates against foodborn bacteria. Korean J Food Sci Technol 29: 808-816

31. Badami S, Moorkoth S, Suresh B (2004) Caesalpinia sappan A medical and dye yielding plant. Nat Prod Radiance 3:75-82

32. Athinarayanana G, Ranjitsingh AJA, Usha Raja Nanthini A, Padmalathad C (2017) Toxicological studies of Caesalpinia sappan wood derived dye in Wister albino rats. Food Sci Hum Well 6: 34-38 